\section{In Vitro Propagation of Jícama (Polymnia sonchifolia Poeppig \& Endlicher): A Neglected Andean Crop}

Jaime E. Estrella ${ }^{1}$

Plant Genetic Resources Department, Instituto National Autónomo de Investigaciones Agropecuarias, Casilla Postal 340, Quito, Ecuador

Jaime E. Lazarte ${ }^{2}$

Blood Research and Development Laboratory, Division of Center for Blood Research Laboratory, Harvard Medical School, Boston, MA 02135

Polymnia sonchifolia, a Composite commonly referred to as jícama, yacon, or aricoma, is an Andean distant relative of the sunflower. Jícama is grown for its edible tubers that usually are eaten raw. Its flavor has been described as similar to a fresh-picked apple with a sweet taste reminiscent of watermelon (National Research Council, 1989). The plant grows at medium altitudes $900-2750 \mathrm{~m}$ in the Andean highlands of Colombia, Ecuador, Perú, and Bolivia, but it has been cultivated at elevations up to $3400 \mathrm{~m}$ in Ecuador (Castillo and Nieto, 1990; Hermann, 1992; Nieto et al., 1984). This neglected plant is part of the diversity of crops that served as important storage food during the evolution of the Andean civilization, which emerged $\approx 4500$ years ago. Roots and tubers of most species store carbohydrates in the form of starch, a glucose polymer. Jícama, however, stores carbohydrates in the form of inulin (fructose). Thus, its cultivation could provide dietetic products and perhaps a natural sugar substitute (Hermann, 1992).

Jícama is a herbaceous plant propagated easily from offset, stem cuttings and tuber divisions. However, an in vitro propagation method to establish, propagate, and maintain

\footnotetext{
Received for publication 13 Apr. 1993. Accepted for publication 16 Oct. 1993. This research was supported by Instituto National Autónomo de Investigaciones Agropecuarias and the Programa de Tecnología Agropecuaria from Ecuador. A fellowship from Harvard Univ. and a grant from Fundación Capacitar, Committee of Latin American \& Iberian Studies, and the Latin American Scholarship Program of American Universities permitted the writing and publication of this article. The cost of publishing this paper was defrayed in part by the payment of page charges. Under postal regulations, this paper therefore must be hereby marked advertisement solely to indicate this fact.

'Visiting Scholar at Harvard Univ. and Interim Head of the Plant Genetic Resources Dept. To whom reprint requests should be addressed.

${ }^{2}$ Lecturer and Researcher.
} propagation. Data are means of 10 replications. response was obtained with $4.4 \mu \mathrm{MBA}$ and $0.49 \mu \mathrm{M}$ IBA, which provided the shortest time to budbreak, the highest levels of shoot development, and the most shoots and roots per plantlet (Table 1). BA was not removed from the medium for rooting because, for germplasm conservation, it is important to induce shoot development and some rooting. Jícama rooting was not inhibited by the cytokinin BA. Two to three explants were used per Magenta container for reculturing every 4 weeks. In treatments with $44 \mu \mathrm{M} \mathrm{BA}$ and $4.9 \mu \mathrm{M}$ IBA, 16.2 days were needed to budbreak. A total of $40 \%$ of cultures developed shoots, and 2.9 shoots and 2.2 roots per plantlet were recorded. Explants treated with $0.4 \mu \mathrm{MBA}$ and $0.05 \mu \mathrm{M}$ IBA grew more slowly, and only half developed shoots. They had fewer shoots and showed low rooting levels compared to plants with 10 times higher levels of growth regulators. Explants cultured on medium lacking plant growth regulators did not develop shoots or roots (Table 1), but callus masses proliferated. Plantlets (with shoots $2-3 \mathrm{~cm}$ long and roots $>3 \mathrm{~cm}$ long) that were transplanted to sandy loam soil, covered with transparent plastic cups to retain humidity, and shaded $40 \%$ were acclimatized successfully in 4 weeks.

The micropropagation procedure established through this research has subsequently permitted the preservation of $>28$ collected jícama genotypes in INIAP's Ecuadorian germplasm bank.

\section{Literature Cited}

vals in sterile distilled water. Explants $(1-2$ $\mathrm{mm})$ were excised from axillary buds and placed in $18 \times 150$-mm test tubes containing 5 $\mathrm{ml}$ of establishment medium composed of MS basal medium (Murashige and Skoog, 1962) plus $4.4 \mu \mathrm{M}$ 6-benzylaminopurine (BA), 0.49 $\mu \mathrm{M}$ indole-3-butyric acid (IBA), 3\% sucrose, and $0.8 \%$ Difco Bacto agar. The $\mathrm{pH}$ was adjusted to 5.7 before autoclaving for $15 \mathrm{~min}$ at 121C. Explants were cultured at $20 \pm 2 \mathrm{C}$ under a 16-h photoperiod $\left(40-50 \mu \mathrm{mol} \cdot \mathrm{m}^{-2} \cdot \mathrm{s}^{-1}\right)$.

Shoot development and rooting. Combinations of BA and IBA in concentrations 10 times below and above the establishment medium were compared for their effect on axillary budbreak and shoot and root development. Each treatment was replicated 10 times in $7.5 \times 7.5 \times 10$-cm Magenta GA7 (Chicago) vessels containing $20 \mathrm{ml}$ of medium. The best
Castillo, R. and C. Nieto. 1990. Ecuador increases Andean crop conservation and development work. Diversity 10:13-14.

Hermann, M. 1992. Raíces y tubérculos andinos: Prioridades de investigación para un recurso alimentario pospuesto. Centro Internacional de la Papa, Lima, Perú.

Murashige, T. and F. Skoog. 1962. A revised medium for rapid growth and bioassays with tobacco tissue cultures. Physiol. Plant. 15:479497.

National Research Council. 1989. Lost crops of the Incas: Little-known plants of the Andes with promise for worldwide cultivation. National Academy Press, Washington, D.C.

Nieto, C., J. Rea, R. Castillo, and E. Peralta. 1984. Guía para el manejo y preservation de los recursos fitogenéticos, INIAP, Quito, Ecuador.

Table 1. Effect of BA and IBA on budbreak and shoot and root development of jicama during in vitro

\begin{tabular}{lccccc}
\hline \hline \multirow{2}{*}{$\begin{array}{c}\text { Growth } \\
\text { regulator }(\mu \mathrm{M})\end{array}$} & $\begin{array}{c}\text { Time to } \\
\text { budbreak }\end{array}$ & $\begin{array}{c}\text { Shoot } \\
\text { development }\end{array}$ & & \multicolumn{2}{c}{ Avg no. } \\
\hline BA & IBA & $($ days $)$ & $(\%)$ & Shoots/explant & Roots/plantlet \\
\cline { 4 - 6 } & 0.00 & -- & 0 & 4 & 0.0 \\
0.4 & 0.05 & 20.0 & 50 & 4.3 & 6.0 \\
4.4 & 0.49 & $10.1^{* *}$ & $90^{* *}$ & $7.6^{* *}$ & $12.4^{* *}$ \\
44.0 & 4.90 & 16.2 & 40 & 2.9 & 2.2 \\
\hline
\end{tabular}

${ }^{* *}$ Significant difference between the treatment noted and all others, using $\mathrm{F}$ test at $P<0.01$. 